\title{
PSYCHOSOCIAL CORRELATES OF CAREER MATURITY OF SECONDARY SCHOOL TEACHERS IN SOKOTO METROPOLIS, SOKOTO STATE, NIGERIA
}

\author{
FATAI MUSTAPHA \\ ISSA GAATA ABDULLAHI \\ BENRET RINGPON JOSEPH
}

Department of Educational Foundations, Usmanu Danfodiyo University, Sokoto, Nigeria.

\begin{abstract}
The study investigated psychosocial correlates of career maturity of secondary school teachers in Sokoto metropolis. The population of the study was all 1,298 teachers in 25 public secondary schools in Sokoto metropolis. The sample size of 297 teachers was selected using proportionate random sampling technique. Three instruments were used for data collection. They include an adopted version of Jung's Typology Test (16 Personality Questionnaire) to measure personality type. The instrument was validated by experts in counselling and measurement at Usmanu Danfodiyo University, Sokoto, and co-efficient of 0.68 was returned for the instrument when it was tested for reliability. The second instrument as Bakare's Vocational Interest Inventory (VII) that was used to measure vocational interest of the respondents and its validity and reliability were obtained and documented by Bakare, The third instrument was Tambawal's (2001) Career Maturity Inventory Attitude Scale (CMIAS) used to measure teachers' career maturity which was validated and its reliability was obtained by Tambawal. Three research hypotheses were formulated and tested using Pearson Product Moment Correlation Co-efficient, and Multiple Regression analysis at 0.05 level of significance. The study found significant relationship between career interest and career maturity of secondary school teachers, but found no significant difference between personality and career maturity of secondary school teachers. The study recommended that Sokoto state chapter of Counselling Association of Nigeria (CASSON) should, on a regular basis, organise seminars, workshops and symposia for teachers to furnish them with information on the types of personality that fit different careers and how they can manage their personality to grow in their chosen careers.
\end{abstract}

Keywords: Psychosocial Correlates, Career Maturity, Secondary School Teachers DOI: $\quad$ https://doi.org/10.35386/ser.v18i1.51

\section{Introduction}

The development of career of an individual involves many variables; some of these variables include career interest, personality type, self-concept, motivation and so on. Kochhar (2007) explains that people started developing interest in choosing a career that will lead to maturity considering some of these variables. Thus, career choice does not happen in isolation, but in congruence with the general development of an individual. For an individual to select a career he/she is expected to have interest in that career. When individuals are able to identify their careers of interest, it is important to match that career with their personality type. Holland in Coertse and Schepers (2004) linked personality to specific activities and occupations. Holland's personality type explains that whether a person is satisfied in his/her job or not depends on the similarity between their personality types, career choices and the environment. 
Career interest perfectly matched with personality type is instrumental in achieving satisfaction in the world of work. Tambuwal (2010) postulated that career adjustment of an individual should consist of personal as well as environment competence. This statement brings in the concept of self. Therefore, one can conclude by saying that the self-concept of individuals in relation to their career interests and personality types will offer a better future for their career. This is supported by Salawu as cited in Kibiya (2014) that view self-concept as an overall constellation of individual's psychological characteristics. Therefore, if individuals select careers that fitthem and personality types, they can easily judge whether their choices and interests will lead to a successful career or not.

Teaching requires responsiveness, commitment and accountability. It requires special people who can really sustain the career world. It is assumed that by the end of secondary school, adolescents have sufficient knowledge of the world of work and are in a good position to make career choices.

The quality of a teacher is dependent on his/her preparation for professional role of teaching. The occupation of a person has important consequence, it is the pivot on which basic life goals and values rest. In view of the importance of career on an individual, Super in Coertse and Schepers (2004) maintained that in order to make the right career choice a person should display certain level of maturity. Career maturity therefore is the representation of place reached on the continuum of vocational development from exploration to decline.

According to Crites in Gonzalez (2008) career maturity is essential in the choice of career. A career-matured individual will gather information about the self in order to gain insight and obtain the necessary competencies in order to make an informed decision, integrate self-knowledge and knowledge of the world of work. It is in view of this, that the researcher was prompted to conduct this research aimed atstudying whether career interest and personality type relateto career maturity.

\section{Statement of the Problem}

Career interest and personality are important variables that are fundamental to one's career choice and development. However, people seem to enter into a career not considering any of these variables. This often happens because of many graduates from different fields of study lack career opportunity in their profession and end up embracing teaching as last option not necessarily as career of their interest. This means that many teachers found themselves in the career as an accident; such teachers often struggle with problems such as lack of motivation, poor interpersonal relationship, lack of competence, lack of job satisfaction just to mention but a few. Bearing this in mind the National Policy on Education (NPE, 2014) clearly articulated the importance attached to teacher education in affirming that 'no educational system can rise above the quality of its teachers'. Where teachers struggle with problems such as mentioned earlier, they gradually lose interest in discharging their duty. Apart from the fact that some teachers found themselves as teachers by accident, others lack proper guidance as to which career best suit their personality types as well as selfconcepts. Lack of proper information about career choice makes some others to relegate teaching to feminine gender. These are some of the problems capable of 
rendering a teacher ineffective. It is in view of this that the researcher embarked on the study to investigate whether career interest and personality type correlate with career maturity.

\section{Literature Review}

Literature reviewed here include the concept of interest, personality and career maturity. There is need for conceptual framework of these variables in order to provide the clarity on them since they are the variables of interest in this study.

\section{Career Interest}

Interest is one of the psychosocial variables that was correlated with career maturity of secondary school teachers in Sokoto metropolis. Interest is one of the most effective steps in the realization of any activity. Interest is defined according to Colman in by Kibiya (2014) as the liking/disliking state of mind accompanying the doing of an activity, or the thought of performing the activity. An individual needs assistance to understand the basic skills in developing interest and should be guided to understand and appreciate the relationship that exist between interest and career development at the early and later stage of life; by doing this, the individual may be prevented from vocational burnout (Bartley, 2005).

Interest is the driving force that pushes an individual to choose and aspire for a certain career in life for the purpose of personal and societal development. Ibrahim (2010) states that career interest of an individual serves as the sailing boat of one's role in the whole life span. Similarly, Beck (2005) is of the opinion that it is interest that motivates a person to aspire, decide, establish and develop in times of vocation thereby attending the peak of maturity in his or her career as well as job satisfaction. Consequently, an individual functions better and is more productive as well as derives personal satisfaction when he/she engages in a career of his/her interest (Mansell, Broughand, \& Cole, 2009). Holland's in Coertse and Schepers (2004) categorization of interest area RIASEC falls in line with the above explanation and views on interest. These areas of interest signify that individual and group aspire for a career and develop it according to their interest or need. As such, functional Counseling program should be put in place in teacher training institutions to assist teachers acquire the skill of interest development (Kibiya, 2014).

\section{Concept of Personality}

Personality is defined as 'the integrated and dynamic organization of individual's psych, social,moral and physical characteristics in interaction with the environment' (Herr, 2001). Based on the above definition personality is a multi-dimensional variable. It is both psychological as well as social and also a moral variable. It is assumed from the above definition that people differ in terms of personality type, this in turn affect or influence their career attainment. Personality is the dynamic organization with the individual of those psychophysical systems that determine his characteristics behavior and thought (Allport, 1961). The idiographic view assumes that each person has a unique psychological structure and that some traits are possessed by only one person, and that there are times when it is impossible to compare one person with others. It tends to use case studies for information gathering. 
Psychosocial Correlates of Career Maturity of Secondary School Teachers in Sokoto Metropolis, Sokoto State, Nigeria

The nomothetic view, on the other hand emphasizes comparability among individuals. This viewpoint sees trait as having the same psychological meaning in everyone. This approach tends to use self-report personality questions, factor analysis, etc. People differ in their positions along a continuum in the same set of traits and the promotion of part of gender equal opportunities policies a high priority".

The personality of an individual affects their vocational choice and development. TorAnyiin in Kibiya (2014), asserts that the personality of an individual encompasses temperament as well as attitude, social relations, aptitude, values and life skills. In essence personality entails an individual uniqueness. Anestassi in Kibiya (2014) maintained that choosing a career often implies the choice of general life style. Coertse and Schepers (2004) pointed out that several personality variables have influence on career development and an individual's ability to effectively plan and choose a career.

\section{Career Maturity}

Super in Coertse and Schepers (2004) defines career maturity as a constellation of physical, psychological and social affective, it includes the degree of success in coping with the demands of earlier stages and sub-stages of career development especially with most need. Super further explains that career maturity is an individual readiness to cope with the development task with which he or she is confronted due to biological and social development with social expectation, from those who have reached the stages of development. Career maturity is the peak of one's career.

Career or vocational maturity as its sometimes called is a construct that has been investigated, and measured, and debated for over 30 years (Coertes and Schepers, 2004). According to Super in Coertse and Schepers (2004) the person who first used the term career maturity in his career development theory defined career maturity as the extent to which an individual has mastered the age appropriate vocational tasks relevant to his or her development stage. This is to say that teachers are career matured if their decision to become teachers is tentative and that they have gained knowledge about education and occupational alternatives. Every individual need help to acquire necessary skills to be able to balance between school and work. As such the educational system in every society should provide information that will lead an individual from school to career. Lai in Kibiya (2014 p.25) identified the following stages for individual to mature in their career, these are:

1. Gathering information about oneself thereby converting the information into self -knowledge.

2. Acquiring decision making skills as well as putting them into application when it comes to taking decisions.

3. Procurement of career information and converting it into the world of work.

4. Pairing self- knowledge with information of the world of work.

5. Planning and implementing for successful career development.

Apart from Lai's classification, Kochhar (2007) also classified stages of career maturity as follows: 


\section{Individual self-assessment}

1. Exploring and research option

2. Declining and setting goals

3. Developing a plan and implementation

4. Reflection and evaluation

5. Individual self-assessment.

Parson in Kochhar (2007) argued that man should analyse the foundation for career choice, and the analysis should be done on careful study of individual's capabilities, abilities, interest, aptitude and temperament. Therefore, self-assessment is the starting point in the choice and development of career.

\section{Exploring and Researching options}

At this stage, the world of work should be explored to bring various options available for the individual to see and relate it to interest and ability thereby selecting the better option.

\section{Decline and Setting goals}

This is the stage of concrete interest development on the type of career to choose thereby making all possible efforts to achieve career maturity.

\section{Developing a plan and implementation}

At this stage, Parkes, Farmer \& Carnell (2004) proposed that the individual is putting oneself in the circle of a specific career according to the connected relationship between the person and the job.

\section{Decline and Evaluation}

At this stage the job is expected to reflect the personality of the individual. That is to say that the job would shape the personality of the individual while the individual modifies the job for possible adjustment, job crisis management as well as general preparation for safe landing in the career.

Career guidance will serve a good purpose in assisting individuals to increase the ability to make career decision that will lead people to career maturity, reducing educational wastage and unemployment.

Many researches have clearly identified the relationship that exists between interest and career maturity. Popa and Butnaru (2008) opined that matching an individual's interest and ability as well as job requirement would determine success in general career development resulting to the attainment of career maturity. Rama as quoted in Kibiya (2014) in his research conducted to measure the existing relationship between career and Job satisfaction among secondary school teachers. The result shows that a significant relationship exists between interest and job satisfaction. Considering the findings of this research, it is pertinent for one to say that interest is the gateway to the 
Psychosocial Correlates of Career Maturity of Secondary School Teachers in Sokoto Metropolis, Sokoto State, Nigeria

realization, readiness competence as well as functional development in career.A research was conducted using a sample of 1476 first-year students at a South African University. Some personality variables were correlated using the 16-personality factor questionnaire in a research conducted by Coertse and Schepers (2004), and it was evident that several of the analysis of variance are statistically significant.

\section{Methodology}

The research design that was used for this research is correlational design.Tambuwal (2001) considered correlational study as a frequently used type of research that is concerned with determining extent of relationship existing among variables. The population of this study comprised all teachers in all public secondary schools within Sokoto metropolis. There are 27 state public secondary schools within Sokoto metropolis and a total of 1,298 teachers in these schools according to data obtained from Sokoto State Teachers Service Board as at October, 2018The sample for this study was drawn from all the teachers in only senior secondary schools involving eight schools in Sokoto metropolis. Simple random sampling technique was used in selecting the eight schools and the teachers. The total number of teachers in the eight selected schools was 466 from which 297 were selected. The sample size determination was guided by Krejcie and Morgan (1970) table.

\section{Data Collection Instruments}

Three sets of instruments were used by the researcher to measure teachers' personality type career interest, and career maturity and these instruments were adopted by the researcher. The following are the instruments:

Adopted version of Jung's Typology Test (16 personality Questionnaire) to measure personality type. Validity was ascertained through scrutiny of items by experts/reviewers in counselling and measurement at Usmanu Danfodiyo University, Sokoto for construct validation. The reliability coefficient of 0.68 was obtained through test re-test method of reliability by the researcher.

Adopted version of Bakare Vocational Interest Inventory (VII) to measure vocational interest of an individual. Validity and reliability of the instrument was established and documented by Bakare (1976). The Bakare's Vocational Interest Inventory (VII) is reliable to be used in collecting data on the vocational interest of Secondary School Teachers in Sokoto metropolis

Adopted version of Tambawal (2001) Career Maturity Inventory Attitude Scale (CMIAS) to measure Teachers' career maturity. Validity and reliability of the instrument was established and documented by Tambawal (2001).

\section{Research Questions}

This research examined whether there are relationship between teacher's career interest and personality on their career maturity. Hence, the following questions guided the study: 
What is the relationship between career interest and career maturity of secondary school teachers in Sokoto metropolis?

What is the relationship between personality and career maturity of secondary school teachers in Sokoto metropolis?

Which of these variables; career interest and personality best predict career maturity of secondary school teachers in Sokoto metropolis?

\section{Objectives of the Study}

The objective of this study was to find out the relationship between;

1. Career interest and career maturity of secondary school teachers in Sokoto metropolis.

2. Personality and career maturity of secondary school teachers in Sokoto metropolis.

3. Relationship among these variables; career interest and personality is more related to career maturity of secondary school teachers in Sokoto metropolis.

\section{Research Hypotheses}

The following null hypotheses were tested.

Ho1- There is no significant relationship between career interest and career maturity of secondary school teachers in Sokoto metropolis.

$\mathrm{H}_{\mathrm{O}^{-}}$There is no significant relationship between personality and career maturity of secondary school teachers in Sokoto Metropolis.

$\mathrm{H}_{\mathrm{O}^{-}}-$Career maturity is not significantly related to career interest and personality of secondary school teachers in Sokoto metropolis.

\section{Analyses and Interpretation of Results}

Table 1: Relationship between Career Interest and Career Maturity $(\mathrm{N}=297)$

\begin{tabular}{lcccccl}
\hline Variables & $\mathrm{N}$ & Mean & Std. Deviation & r-Cal & P-value & Decision \\
& & & & & & \\
\hline Career Interest & 297 & 365.8 & 54.8 & & & \\
\hline Career Maturity & 297 & 79.4 & 5.9 & .137 & .018 & Significant \\
\hline
\end{tabular}

From the result of table 1, career interest and career maturity of secondary school teachers were positively related and significant, Pearson's $r=.137, p=.018$. This indicates that there was significant relationship between career interest and career maturity of secondary school teachers in Sokoto metropolis because the p-value (.018) is less than the .05 level of significance. Therefore, the hypothesis which states there is no significant relationship between career interest and career maturity of secondary schools teachers in Sokoto metropolis was rejected. This means that career interest can influence career maturity of secondary school teachers in Sokoto metropolis. 
Psychosocial Correlates of Career Maturity of Secondary School Teachers in Sokoto Metropolis, Sokoto State, Nigeria

Table 2: $\quad$ Relationship between Personality and Career Maturity $(\mathrm{N}=297)$

\begin{tabular}{llllll}
\hline Variables & N & Mean & Std. Deviation r-Cal P-value Decision
\end{tabular}

\begin{tabular}{lllllll}
\hline Personality & 297 & 218.6 & 22.4 & & & \\
\hline & & & & .436 & .000 & Significant \\
Career Maturity & 297 & 79.4 & 5.9 & & & \\
\hline
\end{tabular}

From the result of table 2, personality and career maturity of secondary school teacher were positively related and significant, Pearson's $\mathrm{r}=.436, \mathrm{p}=.000$. This indicates that there was significant relationship between personality and career maturity of senior secondary school teachers in Sokoto metropolis because the p-value (.000) is less than the .05 level of significance. Therefore, the hypothesis which states there is no significant relationship between personality and career maturity of secondary schools teachers in Sokoto metropolis was rejected. This means that the teachers' personality has influence on their career maturity in Sokoto metropolis.

Multiple Regression Analysis of Personality and Career Interest on Career Maturity of Secondary School Teachers

\begin{tabular}{lllllllll}
\hline Variables & $\mathrm{R}$ & $\mathrm{R}^{2}$ & $\begin{array}{l}\text { Adjusted } \\
\mathrm{R}^{2}\end{array}$ & $\mathrm{SE}$ & $\mathrm{F}$ & $\mathrm{B}$ & $\mathrm{T}$ & $\begin{array}{l}\mathrm{P}- \\
\text { value }\end{array}$ \\
\hline Personality & .436 & .190 & .187 & 5.24 & 69.15 & .450 & 8.76 & .000 \\
Career Interest & .468 & .219 & .213 & 5.16 & 41.17 & .164 & 3.19 & .002 \\
\hline
\end{tabular}

\section{Dependent Variable: Career Maturity}

A look at the squared part correlations revealed that personality accounts for $1.9 \%$ of the variance in career maturity $\mathrm{R}^{2}$ adj $=.187 \mathrm{~F}(1,295)=69.15, \mathrm{p}<.05$. The influence of career interest accounted for $2.19 \%$ of the variance in career maturity $R^{2}$ adj $=.213$ $\mathrm{F}(2,294)=41.17, \mathrm{p}<.05$. Thus, the significant results of the procedure indicated that personality was able to account for significant amount of variance in the dependent variable (career maturity). Although career interest is related variable to career maturity, analysis of regression coefficients indicated that personality, $\beta=.450$, $\mathrm{t}=8.76, \mathrm{p}<.05$ emerged as themore related variable to career maturity than career interest. Thus, this means that personality is more related to career maturity of secondary school teachers than career interest of teachers.

\section{Discussion of the Findings}

It was revealed that career interest was significantly related to career maturity of secondary school teachers in Sokoto metropolis. This finding is in accordance with the finding of Kibiya (2014) in which there is positive relationship between career interest and career maturity. Another finding which support this finding is that of Okon (2001) who opined that interest in career lead to the general development of that career thereby culminating into establishing and developing a career. Therefore, in order to develop fully in one's career solely depends on the amount of interest one has in the career.

It was found that personality of secondary school teachers in Sokoto metropolis was significantly related to their career maturity. This finding is in line with the finding of 
Coertse and Schepers (2004) who reported that career matured students are practically minded rather than imaginative, astute, self- assured and generally more controlled and relaxed. Furthermore, the career matured individuals are those that possess the strong personality types while the immature individuals possess weak personality types. This is to say that strong personality positively influences career maturity.Therefore, one should compare his/her personality type and their choice for a better success.

It was found that personality was more related to career maturity of secondary school teachers than their career interest. Although career interest is related to career maturity, analysis of regression coefficients indicated that personality, $\beta=.450, \mathrm{t}=$ $8.76, \mathrm{p}<.05$ emerged as themore related variable to career maturity than career interest. This finding supports the finding of Coertse and Schepers (2004) in which they reported that personality predict career maturity of an individual.

\section{Conclusion}

From the findings and discussion of the results, it was concluded that there was significant relationship between career interest and career maturity as well as significant relationship existed between personality and career maturity of secondary school teachers in Sokoto metropolis.

\section{Recommendations}

Based on the finding of this study, it was recommended that;

To record better result in the profession of teaching, teachers in the state should be motivated in their job by a due payment of their entitlement, frequent promotion, accommodation and transport allowances e.t.c. This will boost their interest in teaching which will lead to their development in the job.

The Sokoto state chapter of Counselling Association of Nigeria (CASSON) on a regular basis should organize seminar, workshop and symposia for teachers to furnish them with information on the types of personality that fit different careers and how they can manage their personality to grow in their chosen career.

When personality is mismatched with a chosen career, to grow in that career with be very difficult. Therefore, it is recommended that one should understand one's personality and match it to appropriate career when chosen career which can guarantee a successful career. 
Psychosocial Correlates of Career Maturity of Secondary School Teachers in Sokoto Metropolis, Sokoto State, Nigeria

\section{References}

Allport, G. W. (1961). Pattern and Growth in Personality. New York: Holt, Rinehart, \& Winston.

Bakare, C. G. M. (1976). Motivation for Occupational Preference Scale (Questionnaire) Psycho educational Research Productions.

Bartley, A. E. (2005). Correlates of Occupational Burnout in Counsellor Educators. Unpublished Ph. D Thesis. Oregon State University.

Beck, R. C. (2005). Motivation. Theories\& Principles. Fourth Edition. India: Pearson Education.

Coertse, S. \& Schepers, J. M. (2004). Some Personality Correlates of Career Maturity. South African Journal of Industrial Psychology. 30 (2): 56-73.

Federal Government of Nigeria, (2014); National Policy on Education.

Gonzalez, A. M. (2008). Career maturity: a priority for secondary education. An electronic journal of educational psychology. ISSN. 1696-2095. 16 (3): 749772 .

Herr, E. L. (2001). Career Development and its Practice: A Historical Perspective. Career Development Quarterly, 3: 1-16.

Ibrahim, Y. B. (2010). Effect of Group Career Guidance on Vocational Interest of Senior Secondary School Students in Katsina State. Unpublished M. Ed Dissertation, Bayero University, Kano.

Jung, C. G. (1971). Psychological types (Collected works of C. G. Jung, volume 6, Chapter X.

Kibiya, Y. M. (2014). Career Interest, Self-concept and Attribution as Predictors of Career Maturity among Lecturers of Kano State Tertiary Institutions. M. Ed Dissertation. Usmanu Danfodiyo University, Sokoto.

Kochhar, S. K. (2007). Guidance and Counselling in Colleges and Universities. New Delhi: Sterling Publishers Private Limited.

Krejecie R. \& Morgan D. W. (1970). "Determining Sample Size for Research Activities. Educational and Psychological Measurement,"

Mansell, A; Brough, P; \& Cole, K. (2009). Stable Predictors of Job Satisfaction, Psychological Strain and Employee Retention: An Evaluation of Organizational Change within the New Zealand Customs Service. International Journal of Stress Management. 13 (1): 84-107. 
Okon, S. E. (2001). Education and Work: Career Planning and Decision Making. Zaria: Ahmadu Bello University Press.

Parkes, J. R; Farmer, E. \& Cornell, S. (2004). Psychological Aspects of Work and Health in the North Sea oil and gas industry. Oxford: Open University of Oxford.

Popa, N. L. \& Butnaru, S. (2008). Attributional Style and Prevailing Vocational Orientations among University Student in Humanities. $4^{\text {th }}$ International Conference on Educational Technology. Romania.

Tambawal, M. U. (2001). Relationships among Self-concept, Self-other motivation and Career Maturity of Teachers in Tertiary Institutions in Sokoto State. Unpublished PhD Thesis. Usmanu Danfodiyo University, Sokoto. 